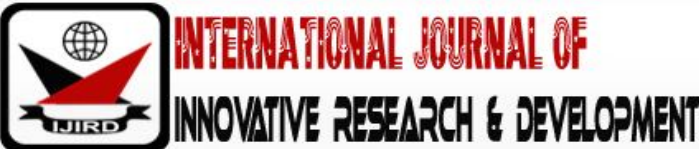

ISSN 2278 - 0211 (Online)

\section{Relationship between Compensation Disparity Factors and Job Satisfaction among Civil Servants: A Survey of Government Institutions in Nairobi County, Kenya}

\author{
Dorcas Mumbi \\ MBA Candidate, Kenya Methodist University, Kenya \\ Thomas Anyanje Senaji \\ Senior Lecturer, Strategy and Knowledge Management, Kenya Methodist University, Kenya
}

\begin{abstract}
:
The objective of the study was to determine the relationship the relationship between compensation disparity factors and job satisfaction among the civil servants in government institutions in Nairobi County, Kenya. It focused on employee on employee rank, level of education, working experience and career advancement. A descriptive research design survey of a stratified random sample of 100 respondents drawn from a target population 237 was conducted in five government ministries and four parastatals in Nairobi County using questionnaires for data collection. The collected data was analyzed using quantitative techniques comprising descriptive and inferential statistics. It was found that the level of education, employee rank, job experience and career development were compensation disparity factors, which means that compensation was differentiated based on these factors and that the four factors were positively and significantly correlated with compensation disparity as perceived civil servants. Further, only job experience based compensation differentiation significantly $(\beta=0.8, \mathrm{p} \varangle 0.001)$ influenced job satisfaction while the level of education, employee rank and career advancement compensation disparity factors did not significantly ( $p>0.05$ for all coefficients) influence job satisfaction in the civil service at $5 \%$ significance level . Besides, the combination of the four factors significantly explain about $30 \%$ of variation in job satisfaction. It is recommended that there be harmonization of salaries by civil service for all civil servants in parastatals and the ministries, and across the job groups. Further, the civil service should review the ranking of employees to ensure promotion on merit and that opportunity should be provided to civil servants to advance their education hence career. Similarly, the number of years the employee has worked should be considered when deciding the compensation in government institutions since it was found to be the most influential compensation disparity factor in predicting job satisfaction. These findings have important implications for the Kenya's salary and remuneration commission regarding compensation policies, and for the human resource managers in government ministries and parastatals in their effort to appropriately motivate staff for high performance.
\end{abstract}

Keywords: Compensation disparity, job satisfaction, civil service, Kenya

\section{Introduction}

Compensation disparity has to do with comparative differences in pay between employees in similar organizations for similar jobs. An employee may feel good about his or her pay in comparison to what those working in other organizations are making. He or she may also believe that the company profits are fairly distributed within the company (Blomme, Van Rheede\& Tromp, 2010). However, this same person may be very unhappy about his or her pay relative to several other people in other organizations. Better performances result only in those who perceive their pay as directly related to performance (Shah \&Anwar, 2007).

Wage differentials have a positive and significant effect on the cost of labor in the public sector. For instance, a Ksh.100 increase in the wage differential leads to an equivalent increase in the cost of labor in the public sector in the long term. This is because the wage differential can be used as a justification for lobbying for higher wages in the public service, as witnessed in recent salary increment calls by teachers, lecturers and doctors (Bozeman \&Gaughan, 2011).

Despite the relative importance played by wages, the overall job satisfaction that an individual derives from an organization is the most significant determinant of whether the individual quits or stays in the public sector. Incentives and 
allowances play a significant role in ensuring employee retention within the public sector. However, basic salaries alone significantly decrease retention chance (Choi \& Lee, 2012).

\subsection{Job Satisfaction}

Job satisfaction or employee satisfaction has been defined in many different ways. Some believe it is simply how content an individual is with his or her job, in other words, whether or not they like the job or individual aspects or facets of jobs, such as nature of work or supervision (Choi \& Lee, 2012). It can also be defined as how contented an individual is with his or her job, in other words, whether or not they like the job or individual aspects or facets of jobs, such as nature of work or supervision. Others believe it is not as simplistic as this definition suggests and instead that multidimensional psychological responses to one's job are involved. Researchers have also noted that job satisfaction measures vary in the extent to which they measure feelings about the job (affective job satisfaction) or cognitions about the job (Gilley, Dixon, \& Gilley, 2008).

One of the most widely used definitions in organizational research is that of Dawson (2013) who defines job satisfaction as "a pleasurable or positive emotional state resulting from the appraisal of one's job or job experiences. It is assessed at both the global level (whether or not the individual is satisfied with the job overall), or at the facet level (whether or not the individual is satisfied with different aspects of the job). Some of the common facets of job satisfaction are Appreciation, Communication, Coworkers, Fringe benefits, Job conditions, Nature of the work, Organization, Personal growth, Policies and procedures, Promotion opportunities, Recognition, Security, and Supervision (Shah \&Anwar, 2007).

\subsection{Compensation}

Compensation refers to the act of providing a person with money or other things of economic value in exchange for their goods, labor, or to provide for the costs of injuries that they have incurred.

Compensation plays an important role in determining employees' job satisfaction; the perception of being paid what one is worth predicts job satisfaction (Hashim \& Mahmood, 2011). If individuals believe they are not compensated well a state of emotional dissatisfaction develops. This emotional discrepancy grows and accumulates over time making employees to grumble as they render their service to the organization. Worse still, indicators such as absenteeism, turn over, go slow and strikes are experienced. Compensation has long been considered one of the most important organizational rewards because it allows employees to obtain other rewards (Pouliakas, 2010).

Compensation has a lot of influence on job satisfaction among civil servants. Lack of job satisfaction in the public sector is thought to be influenced by a number of factors including long hours, night and weekend schedules, stress, demanding supervisors and duties, lack of personal time and quality of life, routine, and little opportunity for advancement and growth. Compensation has a great impact on productivity. In Kenya, there have been a lot of complaints about poor compensation from the civil servants from time to time public servants also walk to the streets to demonstrate against poor compensation. When a job decreases in pay attractiveness, the employee is more likely to be dissatisfied with the job itself (Githinji, 2010). On the other hand, Compensation disparity is comparative differences in pay between employees in similar organizations for similar jobs.

\subsection{Civil Service in Kenya}

Kenya has an estimated 700,000 workers in civil service. The government intends to retrench excess workforce up to a tune of 100,000 civil servants in order to contain its wage bill that currently stands at Sh458 billion per annum. Kenya is divided into 47 counties. Counties are governed by county governments. The counties are led by a county governor and have a county assembly. At each of these levels of administration, there are professionals employed. The Public Service Commission (PSC) of Kenya is an Independent government Commission established under the Constitution of Kenya to manage human resources in the Kenya Civil Service and the Local Authorities (Hashim \& Mahmood, 2011).

In the last 20 years, Kenya's civil service has undergone a number of changes. Some of these changes include employee rationalization leading to wage bill reduction, performance improvement, structural adjustment programme after aid cuts, and the institutionalization of results-based management. From 1993 to 2002, the Government retrenched more than 100,000 civil servants but had only a negligible impact on the effectiveness or efficiency of the civil service. The Government then introduced results-oriented management but by 2005 nothing much had come out of it (Pouliakas, 2010).

Later, between 2006 and 2008, the Government decided to shift the public service towards a results-orientation approach by introducing and facilitating the development and management of a holistic Results-Based Management system through the 'Results for Kenya programme. The aim was to enhance performance efficiency in all government ministries, departments and agencies. It also meant to reverse the negative image of the public service. The Kenyan government needed transformation, particularly attitude change of civil servants. The Constitution has opened space for citizens' participation in public policy making process (Shah \& Anwar, 2007). In 2009, United Nations Development Programme (UNDP) supported the Kenyan government to step up public sector reforms to focus on national transformation. Before then, it was the Government that spearheaded institutionalization of results-based management in the public service but currently the focus is on transforming public service delivery through building partnerships. These efforts were boosted after the promulgation of the new Constitution of Kenya in 2010. 


\subsection{Statement of the Problem}

A new report by the Kenya's Salaries and Remuneration Commission a statutory body in charge of compensation in the public service, has exposed salary disparities between civil servants, showing that the highest paid cadre earn almost 100 times more than to the report, the highest paid civil servants mainly Cabinet Secretaries at Job group V earning mean basic salary of Sh737,332 (over US\$ 7000) while the lowest paid in Job Group A earns a basic salary of Sh7,701 (US\$ 70) per month. The report, which further shows that some constitutional office holders could be earning some allowances illegally, is an indictment on the government's pay structure that has been blamed for the rising public wage bill. This raise concerns on the effects of compensation on job satisfaction among the civil servants (Shah \&Anwar, 2007).

Employees in government ministries are paid less than their counterparts in the government parastatals despite the same qualification, job group, employees rank, job experience and career advancement opportunities which leaves a major compensation disparity gap, this has led to high turnover among employees in the government ministries. Although there are numerous studies on job satisfaction, no study concerning civil servant's compensation has been conducted in various countries, very few have been conducted to address the current pay disparities being experienced in Kenya's civil service. Specifically, there is scarce empirical evidence on perception of compensation disparity, what the compensation disparities (bases of disparity) are and how these compensation disparity factor relates with job satisfaction in the civil service. Evidence on the relationship between perceptions of disparity, employee rank, level of education, working experience, and career advancement on job satisfaction among the civil servants is scarce. The purpose of this was to determine the relationship between compensation disparities factors and job satisfaction among the civil servants' survey of government institutions in Nairobi County Kenya by answering two broad questions: First, what are the compensation disparity factors is the perception compensation disparity factors among civil servants in Kenya? (RQ1); and second, what is the relationship between compensation disparity factors (employee rank, level of education, working experience, and career advancement) and job satisfaction among civil servants in Kenya (RQ2).

\section{Theory and Hypothesis}

This study is underpinned by three theories of motivation, Expectancy theory, Maslow's hierarchy of needs theory and Equity theory

\subsection{Expectancy Theory}

In 1964, Vroom developed the expectancy theory through his study of the motivations behind decision making. Expectancy theory posits that an individual will behave or act in a certain way because they are motivated to select a specific behavior over other behavior due to what they expect the result of that selected behavior will be. In essence, the motivation of the behavior selection is determined by the desirability of the outcome. However, at the core of the theory is the cognitive process of how an individual process the different motivational elements. This is done before making the ultimate choice. The outcome is not the sole determining factor in making the decision of how to behave (Yamoah, 2013).

Expectancy theory which focuses on link between rewards and behavior. In this study the reward is compensation while the behavior is job satisfaction. According to the theory, Motivation is the product of valence, instrumentality and expectancy. Compensation systems differ according to their impact on these motivational components and pay systems differ most in their impact on instrumentality (Boushey\& Glynn, 2012). There is a perceived link between behavior and pay. Employees reports of their satisfaction with their jobs, are directly related to the extent to which their jobs provide them with such rewarding outcomes, as pay, variety in simulation, consideration from their supervisor, a high probability of promotion, close interaction with co-workers, an opportunity to influence decisions and control over their pace of work (Udogo, 2008). Expectancy theory concentrates on the expectations which employees bring with them to work situation and the context and manner in which these expectations are satisfied. The underlying hypothesis is that "appropriate levels of effort, and hence productivity, will only be extended if employees expectations are fulfilled". It does not assume a static range of expectations common to all employees but rather points to the possibility of different sets of expectations (Blomme, Van Rheede \& Tromp, 2010). Rewards are seen as fulfilling or not fulfilling expectations. Expectancy theory challenges management to demonstrate to employees that extra effort will reap a commensurate reward. The link between effort and reward needs to encompass both the pay packet and a variety of other extrinsic or intrinsic rewards. Reward schemes must therefore create a positive link between the size of the pay packet and the effort expended for employees are primarily motivated by money (Bozeman \& Gaughan, 2011).

\subsection{Maslow Hierarchy of Needs Theory}

Maslow's hierarchy of needs is a theory in psychology proposed by Abraham Maslow in his 1943 paper "A Theory of Human Motivation" in Psychological Review. Maslow subsequently extended the idea to include his observations of humans' innate curiosity. His theories parallel many other theories of human developmental psychology, some of which focus on describing the stages of growth in humans. Maslow used the terms "physiological", "safety", "belongingness" and "love", "esteem", "self-actualization", and "self-transcendence" to describe the pattern that human motivations generally move through (Choi \& Lee, 2012). 
Maslow's hierarchy of needs theory states that people have a pyramid hierarchy of needs that they will satisfy from bottom to top. Starting from mere physiological subsistence the Maslow hierarchy of needs covers belonging to a social circle to pursuing your talent through self-actualization. Important to the hierarchy of needs theory is that Maslow felt that unfulfilled needs lower on the ladder would inhibit the person from climbing to the next step (Boushey \& Glynn, 2012). Though Maslow's Need Hierarchy Theory talks about compensation being at the middle to lower rank of the pyramid and the other factors like job satisfaction and fulfillment being at the top, for a majority of employees, getting the right compensation is by itself a motivating factor. Hence, employers need to quantify the employee's contribution in a proper manner if they are to get the best out of them (Dawson, 2013).

\subsection{Equity Theory}

Equity theory focuses on determining whether the distribution of resources is fair to both relational partners. Equity is measured by comparing the ratio of contributions (or costs) and benefits (or rewards) for each person. Considered one of the justice theories, equity theory was first developed in the 1960s by J. Stacy Adams, a workplace and behavioral psychologist, who asserted that employees seek to maintain equity between the inputs that they bring to a job and the outcomes that they receive from it against the perceived inputs and outcomes of others (Dawson, 2013). The belief is that people value fair treatment which causes them to be motivated to keep the fairness maintained within the relationships of their co-workers and the organization. The structure of equity in the workplace is based on the ratio of inputs to outcomes. Inputs are the contributions made by the employee for the organization.

In any position, an employee wants to feel that their contributions and work performance are being rewarded with their pay. If an employee feels underpaid then it will result in the employee feeling hostile towards the organization and perhaps their co-workers, which may result in the employee not performing well at work anymore. It is the subtle variables that also play an important role in the feeling of equity. Just the idea of recognition for the job performance and the mere act of thanking the employee will cause a feeling of satisfaction and therefore help the employee feel worthwhile and have better outcomes (Bozeman \& Gaughan, 2011).

\subsection{Compensation and Employees Satisfaction}

Compensation plays an important role in determining employees' job satisfaction. According to Bozeman and Gaughan (2011), the perception of being paid what one is worth predicts job satisfaction. Teachers in Kenya have always downed their tools lamenting about their compensation which raises concern about their job satisfaction. However, it is not clear the influence compensation has on teacher's job satisfaction to cause the many stand offs. This study therefore sought to establish the effects of compensation on job satisfaction among Secondary school teachers in Maara Sub- County Tharaka-Nithi County Kenya. The objective of the study was to determine the effects of both financial and nonfinancial compensation on job satisfaction. It was established that basic pay, allowances and work environment affects teachers' job satisfaction to a great extent. The research concluded that teachers were highly dissatisfied with all aspects of compensation that they receive.

\subsection{Employee Rank and Job Satisfaction}

Bozeman and Gaughan (2011) carried out the study to determine the impact of pay and employees rank on job satisfaction in higher education institutes of Pakistan. Non-probability random sampling technique and multiple regression analysis were applied and 200 questionnaires were distributed to collect the responses and five- points Likert scale was used to measure the responses. Random selections were made once over a period from public and private universities of Punjab, Pakistan. Results replicate previously available data and precision based. Pay which depends on employee rank has significant influence on job satisfaction but the promotion has less influence and partially significant to the job satisfaction.

\subsection{Level of Education and Job Satisfaction}

Carless and Arnup (2011) investigated how education is related to job satisfaction and to different aspects of wellbeing and symptoms in a nationally representative cohort of middle-aged women and men with children. Moreover, the study aimed to investigate the associations between education, job satisfaction, working-hours, partner status, number of children and various aspects of health. Regardless of gender, a long education was associated with significantly higher levels of general job satisfaction, sense of coherence, self-acceptance, and purpose in life, personal growth and fewer physical and mental symptoms. General job satisfaction was a significant predictor of all health-related measures, apart from purpose in life. On the whole, men reported a better health compared to women who reported significantly more physical as well as psychological symptoms.

\subsection{Job Experience and Job Satisfaction}

Choi and Lee (2012) carried out a study to investigate the effects of job experience, satisfaction and motivation on organizational commitment of the nurses in Ghaem Hospital of Mashhad city, Iran. The results showed a significant correlation of job experience and satisfaction with organizational commitment; but, no correlation was observed between job motivation and organizational commitment. 


\subsection{Career Advancement and Job Satisfaction}

Githinji (2010) carried out a descriptive survey to determine the influence of career development on employee performance in the Public University with reference to Kenyatta University. The study adopted a descriptive research design since the study intended to gather quantitative and qualitative data that would describe the influence of career development on employee performance in the public universities. The study established that training had a positive influence on employee performance in the public university in Kenya. It further revealed that job orientation had a positive influence on employee performance in the public university in Kenya. Job satisfaction can be inferred from the level of performance of an organization upon career advancement of employees. Job satisfaction can also be inferred by assessing the extent to which an employee is willing to stay in the same job in an organization and whether they would recommend someone else to take up employment in the organization they work.

Consistent with the reviewed empirical literature we hypothesize that

- H1: Compensation disparity is practiced in the civil service in Kenya

- H2: Compensation factors (compensate) significantly influence job satisfaction among civil servants in Kenya

\section{Compensation disparity factors}

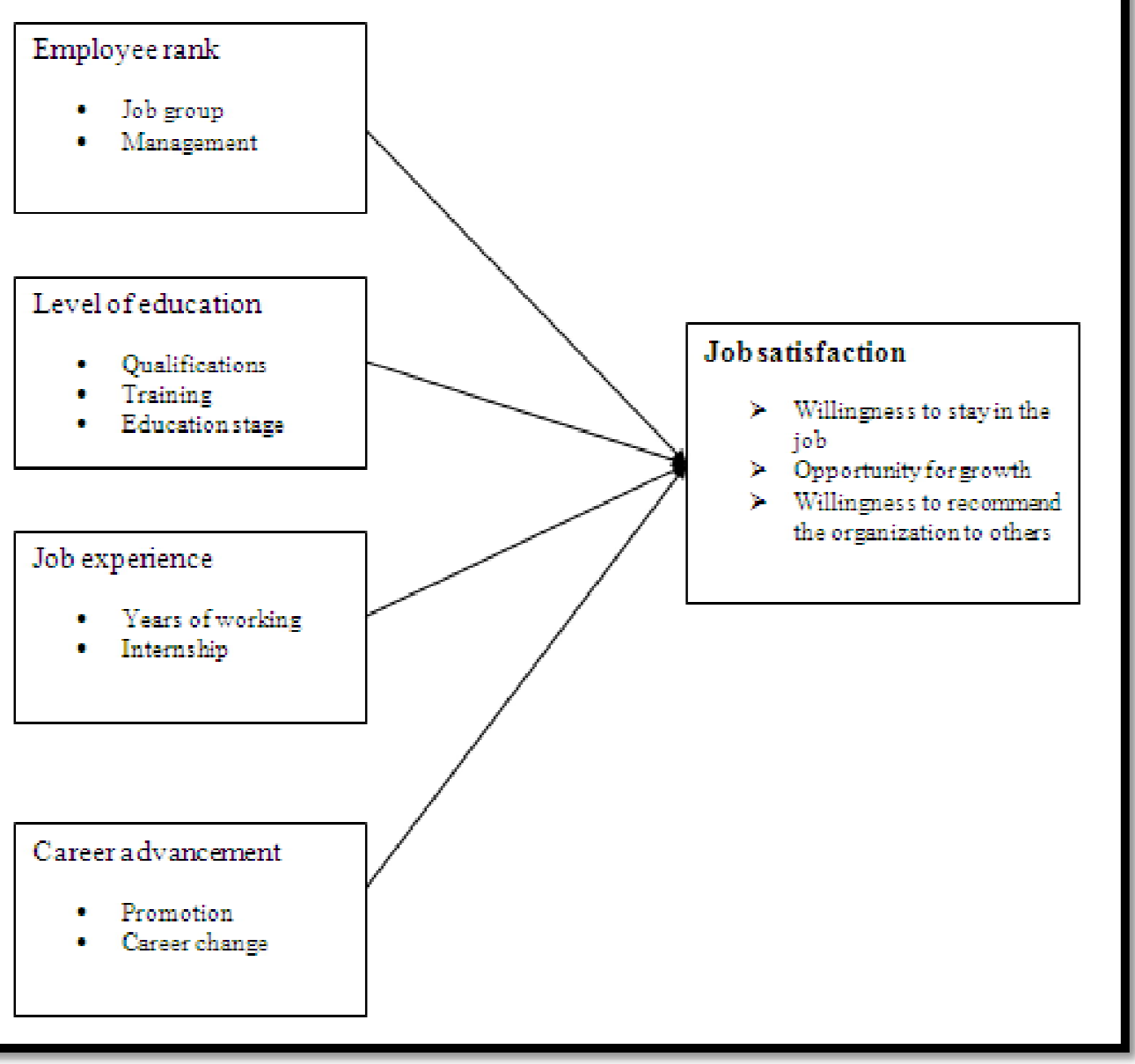

Figure 1: Conceptual Framework

As shown in Figure 1 the conceptualization of the study comprises dependent variable (compensation disparities and job satisfaction), independent variables (employee rank, level of education, job experience and career advancement with some of the indicators (measures) of variables as job group, management, skills, qualifications, training, education stage, years of working, internship, promotion, career change and development.

\section{Methodology}

\subsection{Study Design}

A descriptive survey design was used on a sample of 67 civil servants drawn from five government ministries and four parastatals in Nairobi County which were randomly selected. Descriptive survey design defined by Kothari (2004) as a 
research design that determines and reports the way things are and attempts to describe such things as possible behavior, attitudes, values and characteristics.

\subsection{Population and Sample}

According to Peil (2005), population is a complete set of elements (persons or objects) that possess some common characteristic defined by the sampling criteria established by the researcher.

\subsubsection{Population}

The ministries included Mining (20), Environment and Natural Resource (18), Devolution and Planning (21), Water and Irrigation (16), Finance / National Treasury (28). The parastatals include; Postal Corporation of Kenya (22), National Drought Management Authority (24), Rural Electrification Authority (30), National Environmental Management Authority (36) and Kenya Medical Training College (22).

\subsubsection{Sampling Procedure}

According to Kombo and Tromp (2006), a sampling frame is a comprehensive list of all sampling units, which a sample can be selected. Government ministries and parastatals in Nairobi County were purposively selected and respondents randomly selected from the ministries and parastatals. The sample from the ministries was 52 respondents, comprising Mining (10), Environment and Natural Resource (9), Devolution and Planning (11), Water and Irrigation (8), Finance / National Treasury (14). Similarly, sample from parastatals was 67 comprising Postal Corporation of Kenya (11), National Drought Management Authority (12), Rural Electrification Authority (15), National Environmental Management Authority (18) and Kenya Medical Training College (11).

\subsection{Measures of Variables}

The operational measures of compensation disparity factors, namely employee rank, level of education, job experience, career advancement and job satisfaction

\subsubsection{Employee Rank}

Pay differentials between any two levels in a firm's hierarchy drive employees in the lower level to induce higher effort. Since the best relative performer is promoted in a rank order tournament, higher pay differentials imply a higher compensation on promotion. Employees with higher rank have better pay as compared to employees in lower ranks which lead to job satisfaction in government institutions in Kenya; however, compensation disparities exist between government ministries and parastatals.

\subsubsection{Level of Education}

The level of education determines employee's compensation. Employees with higher education are highly compensated which leads to job satisfaction. In many ways, our two economies have created two separate societies. Those with low educational attainment drift permanently between recessions and depressions, with little stability. Those with high educational attainment experience increased wealth, only mild recessions, and interesting projects with personal growth. There exist compensation disparities between employees in parastatals and government ministries despite the same level of education.

\subsubsection{Job Experience}

Work experience is any experience that a person gains while working in a specific field or occupation, but the expression is widely used to mean a type of volunteer work that is commonly intended for young people often students to get a feel for professional working environments. Work experience can be called a 'placement' or an 'internship'. Internships are sometimes understood to be positions requiring a higher level of qualification than other forms of work experience and are associated with gaining experience for a professional career. There is strong relationship between job experience and pay, higher pay lead to job satisfaction. There exist compensation disparities in government ministries and parastatals despite the job experience.

\subsubsection{Career Advancement}

Career advancement typically refers to getting promoted or being assigned more responsibilities by an employer Some people view career advancement as gaining recognition for quality work in a company. In public sector people advance in their careers by moving from a subordinate role in a department to a leadership role. There is a relationship between career advancement and employees' compensation. Employees in the public sector who have more career advancement opportunities have better pay. Employees in the public sector who have career advancement opportunities are more satisfied with their job. Despite career advancement opportunities, there exist pay disparities in government ministries. 
Compensation disparity Disparity in compensation comprises differences in allowances, wages and salaries. These disparities were considered to be based on compensation disparity factors namely employee ranks, level of education, job experience and career advancement.

Job Satisfaction In this study job satisfaction was observed through proxies such as willingness to stay in the current job, opportunity for growth and willingness to recommend the organization to others.

\subsection{Data Collection Instruments}

Structured questionnaires with statements anchored on a five -point Likert scale and which were tested for both validity and reliability were used. To ensure reliability and validity questionnaires were pre-tested on five respondents in each category of respondents. These respondents included in the final study.

\subsubsection{Validity of Instruments}

The validity of the questionnaire was determined using construct validity method. Construct validity is the degree to which a test measures an intended hypothetical construct. Researcher determined validity by asking a series of questions, and often looking for the answers in the research of others. More resources were allocated to data collection.

\subsubsection{Reliability of instruments}

According to Zikmund (2010) reliability is the extent to which result are consistent overtime and accurate representation of the total population under study is referred to as reliability and if the result of a study can be reproduced under similar methodology the research instrument is considered to be reliable. A high degree of stability indicates a high degree of reliability, which means the results are repeatable. To ensure homogeneity, internal-consistency of instruments was measured using Cronbach's alpha, correlations was run by comparing items determined to be similar. The acceptable thresh hold was above 0.7 (Zikmund, 2010). The reliability analysis of the data collection instruments is presented in Table 1.

\begin{tabular}{|c|c|c|}
\hline Variables & Cronbach's Alpha & N of Items \\
\hline Compensation disparities & 0.505 & 3 \\
\hline Employees Rank & 0.780 & 5 \\
\hline Level of Education & 0.731 & 5 \\
\hline Job Experience & 0.670 & 2 \\
\hline Career Advancement & 0.776 & 4 \\
\hline Job Satisfaction & 0.792 & 4 \\
\hline
\end{tabular}

Table 1: Reliability Statistics

Cronbach's alpha was calculated and used as the test statistic to measure the reliability of the instruments. Cronbach's alpha is a coefficient of reliability that gives an unbiased estimate of data generalizability (Kombo\& Tromp, 2006). An alpha coefficient of 0.50 or higher indicates that the collected data are reliable and have relatively high internal consistency and can be generalized to reflect opinions of all respondents in the target population (Kombo\& Tromp, 2006). Results of the reliability test showed that all constructs depicted value of Cronbach's alpha that are above the suggested value of 0.5 (see Table 1).

\subsection{Data Collection Procedures}

The researcher administered 119 questionnaires individually to all respondents of the study where care was exercised to ensure all questionnaires distributed to the respondents were received.

\subsection{Data Analysis}

The data was cleaned, coded, categorized per each of the research variables and then analyzed using both descriptive analysis with the use SPSS Version 22. While descriptive statistics were used to describe the characteristics if the responses, correlation analysis was used to establish the relationship between the research variables. Lastly, multiple linear regression analysis was used to examine the influence of compensation disparity variables on job satisfaction.

The F- test was used to determine the significance of the regression while the coefficient of determination, $\mathrm{R}^{2}$, was used to determine how much variation in job satisfaction explained by X. This will be done at $95 \%$ confidence level and $5 \%$ significance level.

\subsection{Research Ethics}

Informed consent was obtained from the respondents to ensure that participation in the study was voluntary. The researcher-maintained integrity while conducting the research, analyzing and presenting the data. Further, the researchers took responsibility for the work to be undertaken and for the contribution to the whole study and any consequences that result from the research. 


\section{Results and Discussion}

\subsection{Demographics and Reliability of Instruments}

In this section, the characteristics of the respondents and reliability statistics of the data collection instruments. Out of the 119 questionnaires that were circulated 100 were found to be complete and for use in the analysis.

The distribution of responses by gender, age distribution, highest educational level work experience, and work rank of the respondents are presented, interpreted and discussed as follows:

\begin{tabular}{|c|c|c|c|c|c|}
\hline & & Frequency & Percent & Valid Percent & Cumulative Percent \\
\hline Valid & & 2 & 2 & 2 & 2 \\
\hline & Female & 23 & 23 & 23 & 25 \\
\hline & Male & 75 & 75 & 75 & 100 \\
\hline & Total & 100 & 100 & 100 & \\
\hline
\end{tabular}

Table 2: Gender of Respondents

Table 2 shows $75 \%$ of the respondents were male while $23 \%$ were female this shows that there were more male than females who participated in the study, this shows there was no gender parity in government institutions. Further, the $1 / 3$ rule was not observed (Constitution of Kenya 2010). This implies that more effort is needed to ensure the Constitution is complied with.

\begin{tabular}{|c|c|c|c|c|c|c|}
\hline & & Frequency & Percent & Valid Percent & \multicolumn{2}{|c|}{ Cumulative Percent } \\
\hline Valid & 18-30 Years & 19 & 19 & 19 & 19 & \\
\hline & $31-40$ Years & 36 & 36 & 36 & 55 & \\
\hline & 41-50 Years & 41 & 41 & 41 & 96 & \\
\hline & Above 51 Years & 4 & 4 & 4 & 100 & \\
\hline & Total & 100 & 100 & 100 & & \\
\hline
\end{tabular}

Table 3: Age of Respondents

According to the age distribution of the respondents who participated in the study. Majority of the respondents (41\%) were in 41-50 years age bracket followed by 31-40 years the rest were over 50 years (4\%) and between 18 and 30 years $(19 \%)$. This shows that majority of respondents who participated in the study were young people accounting for $55 \%$ aged between 18 to 40 years.

Data on the level of education was also analyzed and the frequency distributions are presented in Table 4.

\begin{tabular}{|c|c|c|c|c|}
\hline & Frequency & Percent & Valid Percent & Cumulative Percent \\
\hline Not categorized & 1 & 1 & 1 & 1 \\
\hline College & 41 & 41 & 41 & 42 \\
\hline Secondary & 15 & 15 & 15 & 57 \\
\hline University & 43 & 43 & 43 & 100 \\
\hline Total & 100 & 100 & 100 & \\
\hline
\end{tabular}

Table 4: Highest Level of Education

According to the results the highest education level of respondents who participated in the research study. Majority of employees (43\%) had university education, (41\%) college education and (15\%) secondary level education which shows most respondents in public institutions were well educated and are assumed to have provided the required information for the study. Further, the job experience of the employees is shown in Table 5 


\begin{tabular}{|c|c|c|c|c|c|}
\hline & & Frequency & Percent & Valid Percent & Cumulative Percent \\
\hline Valid & Not categorized & 11 & 11 & 11 & 11 \\
\hline & 1-5 Years & 41 & 41 & 41 & 52 \\
\hline & $11-20$ Years & 17 & 17 & 17 & 69 \\
\hline & 21 and above & 4 & 4 & 4 & 73 \\
\hline & 6-10 Years & 4 & 4 & 4 & 77 \\
\hline & Below 1 Year & 23 & 23 & 23 & 100 \\
\hline & Total & 100 & 100 & 100 & \\
\hline
\end{tabular}

Table 5: Work Experience

Table 5 shows the majority of respondents had (41\%) 1-5 years, (4\% (6-10) years, $4 \% 21$ years and above. This implies that majority of respondents who had worked in the organization for a long time. This would suggest that the employees are satisfied with the employer.

Similarly, the frequency distribution for the rank of the employees that were surveyed is presented in Table 6.

\begin{tabular}{|c|c|c|c|c|c|}
\hline & & Frequency & Percent & Valid Percent & Cumulative Percent \\
\hline Valid & Not categorized & 18 & & 18 & 18 \\
\hline & Junior Staff & 40 & 40 & 40 & 58 \\
\hline & Middle Management Staff & 33 & 33 & 33 & 91 \\
\hline & Top Management Staff & 9 & 9 & 9 & 100 \\
\hline & Total & 100 & 100 & 100 & \\
\hline
\end{tabular}

Table 6: Employee Rank

From the results in Table 6 on the work rank of the respondents who participated in the study, majority of respondents (40\%) were junior staff, (33\%) middle management staff and 9\% (6-10) top management staff, this shows that majority of respondents who participated in the study occupied junior positions followed by middle management and lastly top management which represents the usual distribution of staff in an organization. this shows that there was no regular promotion of staff. Extent of disparity practices at the Government Institutions

Descriptive statistics were used to examine the extent to which disparity existed in government institutions. The results are shown in Table 7 (summary statistics) and Table 4.8 for specific aspects of disparity.

\subsection{Summary of Extent of Disparity Perceptions in the Ministries}

Aggregate means and standard deviation variables were calculated to examine the extent of disparities. The descriptive statistics are presented in Table 7.

\begin{tabular}{|c|c|c|c|c|c|c|c|c|c|}
\hline & $\mathbf{N}$ & Minimum & Maximum & Mean & $\begin{array}{c}\text { Std. } \\
\text { Deviation }\end{array}$ & \multicolumn{2}{|c|}{ Skewness } & Kurtosis & \\
\hline & Statistic & Statistic & Statistic & Statistic & Statistic & Statistic & $\begin{array}{c}\text { Std. } \\
\text { Error }\end{array}$ & Statistic & $\begin{array}{c}\text { Std. } \\
\text { Error }\end{array}$ \\
\hline $\begin{array}{c}\text { Compensation disparity } \\
\text { (COAV) }\end{array}$ & 99 & 1.67 & 4.50 & 3.09 & 0.68 & 0.045 & 0.243 & -0.751 & 0.481 \\
\hline $\begin{array}{c}\text { Employee rank (EAV) } \\
\text { Level of Education } \\
\text { (LAV) }\end{array}$ & 99 & 1.20 & 4.60 & 3.53 & 0.67 & -0.74 & 0.243 & 0.265 & 0.481 \\
\hline Job experience (JAV) & 98 & 1.20 & 4.60 & 3.78 & 0.56 & -1.663 & 0.241 & 4.362 & 0.478 \\
\hline $\begin{array}{c}\text { Career advancement } \\
\text { (CAV) }\end{array}$ & 99 & 1.00 & 4.50 & 3.66 & 0.72 & -1.245 & 0.243 & 1.543 & 0.481 \\
\hline Job satisfaction (JSAV) & 99 & 1.25 & 5.00 & 3.88 & 0.84 & -1.324 & 0.243 & 0.959 & 0.481 \\
\hline Valid N (listwise) & 94 & & & & & & & & \\
\hline
\end{tabular}

Table 7: Extent of Disparity Practices in the Ministries

The results in Table 4.7 indicate the extent of disparity perception by employees on four disparity variables Level of education, Job Experience, Employee Rank and Career Advancement. The most highly perceived disparity factor was level of education $(M=3.78, S D=0.56)$ and the least perceived was compensation disparity $(M=3.09, S D=0.86)$. This implies that the most perceived disparity was level of education. Further, the results imply that level of education, job experience, employee 
rank and extent of career advancement of an employee (civil servant) are basis of compensation differentiation (or disparity) among civil servants.

\subsection{Individual Disparity Practices in the Ministries}

The descriptive statistics on the specific aspects of disparity as perceived by the employees are presented in Table.8.

\begin{tabular}{|c|c|c|c|c|c|c|c|c|c|}
\hline \multicolumn{10}{|c|}{ Descriptive Statistics } \\
\hline & $\mathrm{N}$ & Minimum & Maximum & Mean & $\begin{array}{c}\text { Std. } \\
\text { Deviation }\end{array}$ & Ske & & Kurtosis & \\
\hline & Statistic & Statistic & Statistic & Statistic & Statistic & Statistic & $\begin{array}{l}\text { Std. } \\
\text { Error }\end{array}$ & Statistic & Std. Error \\
\hline $\begin{array}{l}\text { COD1-There are big vertical } \\
\text { disparities in wages }\end{array}$ & 99 & 1 & 5 & 2.68 & 1.038 & 0.073 & 0.243 & -1.09 & 0.481 \\
\hline $\begin{array}{c}\text { COD2-There is fair salary across } \\
\text { all job levels }\end{array}$ & 99 & 1 & 5 & 3.18 & 0.919 & 0.031 & 0.243 & -0.783 & 0.481 \\
\hline $\begin{array}{l}\text { COD3-There is fair distribution of } \\
\text { benefits across all job levels }\end{array}$ & 96 & 1 & 5 & 3.40 & 0.900 & -0.433 & 0.246 & -0.573 & 0.488 \\
\hline $\begin{array}{c}\text { ERA1-Employees rank } \\
\text { determines compensation among } \\
\text { employees }\end{array}$ & 99 & 1 & 5 & 2.99 & 1.055 & -0.619 & 0.243 & -0.69 & 0.481 \\
\hline $\begin{array}{l}\text { ERA2-There is harmonization of } \\
\text { pay among all employee ranks }\end{array}$ & 97 & 1 & 5 & 3.42 & 0.945 & -0.34 & 0.245 & -0.678 & 0.485 \\
\hline $\begin{array}{l}\text { ERA3-Job group of employees } \\
\text { determines the level of } \\
\text { compensation. }\end{array}$ & 97 & 2 & 5 & 3.67 & 0.813 & -0.272 & 0.245 & -0.321 & 0.485 \\
\hline $\begin{array}{l}\text { ERA4-Employees level of } \\
\text { management determines } \\
\text { compensation }\end{array}$ & 97 & 1 & 5 & 3.73 & 0.872 & -0.503 & 0.245 & 0.168 & 0.485 \\
\hline $\begin{array}{c}\text { ERA5-Low rank employees are } \\
\text { well compensated in government } \\
\text { institution }\end{array}$ & 98 & 1 & 5 & 3.87 & 0.881 & -0.844 & 0.244 & 0.692 & 0.483 \\
\hline $\begin{array}{l}\text { LOE1-The level of education } \\
\text { determines employees' } \\
\text { compensation among employees } \\
\text { in government institutions }\end{array}$ & 100 & 1 & 5 & 3.55 & 0.796 & -1.086 & 0.241 & 1.794 & 0.478 \\
\hline $\begin{array}{l}\text { LOE2-All employees are well } \\
\text { remunerated irrespective of their } \\
\text { education in government } \\
\text { institutions. }\end{array}$ & 99 & 1 & 5 & 3.68 & 0.879 & -0.603 & 0.243 & 0.158 & 0.481 \\
\hline $\begin{array}{l}\text { LOE3-Employees professional } \\
\text { qualification determines } \\
\text { compensation among employees } \\
\text { in government institutions. }\end{array}$ & 98 & 2 & 5 & 3.80 & 0.773 & -0.176 & 0.244 & -0.355 & 0.483 \\
\hline $\begin{array}{l}\text { LOE4-Employees level of training } \\
\text { determines compensation among } \\
\text { employees in government } \\
\text { institutions. }\end{array}$ & 97 & 1 & 5 & 3.90 & 0.823 & -0.722 & 0.245 & 0.929 & 0.485 \\
\hline $\begin{array}{c}\text { LOE5-Employees level of skills } \\
\text { determines employees } \\
\text { compensation. }\end{array}$ & 100 & 1 & 5 & 3.98 & 0.778 & -0.752 & 0.241 & 1.386 & 0.478 \\
\hline $\begin{array}{l}\text { JOX1-Job experience determines } \\
\text { compensation among employees } \\
\text { in government institution. }\end{array}$ & 96 & 1 & 5 & 3.34 & 0.868 & -0.735 & 0.246 & 0.617 & 0.488 \\
\hline $\begin{array}{l}\text { JOX2-Years of experience in } \\
\text { government institutions } \\
\text { determine employees } \\
\text { 'compensation }\end{array}$ & 94 & 2 & 5 & 3.64 & 0.760 & $\begin{array}{l}-0.483 \\
\end{array}$ & 0.249 & 0.008 & 0.493 \\
\hline $\begin{array}{l}\text { JOX3-Participation in internship } \\
\text { contributes to higher pay among } \\
\text { employees in public institutions. }\end{array}$ & 96 & 2 & 5 & 3.85 & 0.858 & -0.223 & 0.246 & -0.711 & 0.488 \\
\hline $\begin{array}{l}\text { JOX4-Organisation learning } \\
\text { determines compensation among } \\
\text { employees in public institutions. }\end{array}$ & 95 & 2 & 5 & 3.97 & 0.736 & -0.441 & 0.247 & 0.175 & 0.49 \\
\hline
\end{tabular}




\begin{tabular}{|c|c|c|c|c|c|c|c|c|c|}
\hline \multicolumn{10}{|c|}{ Descriptive Statistics } \\
\hline & $\mathrm{N}$ & Minimum & Maximum & Mean & $\begin{array}{c}\text { Std. } \\
\text { Deviation }\end{array}$ & Skewness & Kurtosis & & $\mathrm{N}$ \\
\hline & Statistic & Statistic & Statistic & Statistic & Statistic & Statistic & $\begin{array}{c}\text { Std. } \\
\text { Error }\end{array}$ & Statistic & Statistic \\
\hline $\begin{array}{l}\text { CADV1This ministry provides } \\
\text { equal training opportunities for } \\
\text { all employees to advance their } \\
\text { careers. }\end{array}$ & 97 & 1 & 5 & 3.44 & 1.000 & -0.543 & 0.245 & -0.113 & 0.485 \\
\hline $\begin{array}{l}\text { CADV2-There are compensation } \\
\text { related promotion opportunities } \\
\text { in this organization. }\end{array}$ & 98 & 1 & 6 & 3.57 & 0.885 & -0.312 & 0.244 & 0.687 & 0.483 \\
\hline $\begin{array}{l}\text { CADV3-This organization } \\
\text { encourages personal career } \\
\text { advancement among employees. }\end{array}$ & 96 & 1 & 5 & 3.87 & 0.932 & -0.543 & 0.246 & -0.126 & 0.488 \\
\hline $\begin{array}{l}\text { CADV4-Employees are rewarded } \\
\text { for demonstrating initiatives } \\
\text { regarding their career } \\
\text { advancement. }\end{array}$ & 93 & 1 & 5 & 3.82 & 0.896 & -0.739 & 0.25 & 0.408 & 0.495 \\
\hline JSAT1-My job is exciting. & 98 & 1 & 5 & 3.67 & 1.298 & -0.809 & 0.244 & -0.347 & 0.483 \\
\hline $\begin{array}{l}\text { JSAT2-I am willing to continue in } \\
\text { my current job even if a similar is } \\
\text { available elsewhere. }\end{array}$ & 93 & 1 & 5 & 3.80 & 0.995 & -0.861 & 0.25 & 0.278 & 0.495 \\
\hline $\begin{array}{l}\text { JSAT3-My job provides me with } \\
\text { needed opportunity for growth. }\end{array}$ & 88 & 1 & 5 & 3.92 & 1.020 & -0.836 & 0.257 & 0.216 & 0.508 \\
\hline $\begin{array}{l}\text { JSAT4-I would recommend } \\
\text { someone to take up a job in this } \\
\text { organisation. }\end{array}$ & 90 & 1 & 5 & 4.10 & 1.017 & -1.056 & 0.254 & 0.602 & 0.503 \\
\hline Valid N(listwise) & & & & & & & & & \\
\hline
\end{tabular}

Table 8: Individual Aspects of Disparity in Ministries

On individual attributes of disparity the most important attributes were; for Compensation disparity (There is fair distribution of benefits across all job levels: $\mathrm{M}=3.40, \mathrm{SD}=0.900$ ), Employee Rank (Low rank employees are well compensated in government institution, $\mathrm{M}=3.87, \mathrm{SD}=0.0881$ ), Level of Education (Employees level of skills determines employees compensation, $\mathrm{M} 3.98, \mathrm{SD}=0.778$ ), Job Experience (Organisation learning determines compensation among employees in public institutions, $\mathrm{M}=3.97, \mathrm{SD}=0.736$ ), Career Advancement (Employees are rewarded for demonstrating initiatives regarding their career advancement, $\mathrm{M}=3.87 . \mathrm{SD}=0.932$ ), and finally job satisfaction (I would recommend someone to take up a job in this organisation, $\mathrm{M}=4.10, \mathrm{SD}=1.017$ ). However, it should be noted that there was big variation in the responses on job satisfaction descriptors with standard deviations in excess of $\mathrm{SD}=1.0$ )

The result in Table 8 shows that employees rank - a compensation disparity factor - among employees determines level of compensation as indicated by the statement "employees level of management determines compensation" (M=3.73, $\mathrm{SD}=0.872$ ), this shows that employees in government institutions were remunerated depending in the rank, the higher the rank the higher the remuneration; specifically, this shows that employees on higher levels of management were well compensated as compared to those in lower levels of management.. The finding shows that there is harmonization of pay among all employees ranks in government institutions as evidenced by the mean of 3.42, this shows that there were some efforts to harmonize pay among employees in the ministries. The table shows that job group of employees determines the level of compensation as evidenced by the mean of 3.67; this shows that the higher the job groups the higher the pay among employees, which shows that there was no harmonization of pay on employees from different job groups. Further, low rank employees are well compensated in government institutions as shown by the mean of 3.87, this implies that lower rank employees were well compensated although there existed compensation disparity.

Further, the level of education determines employee's compensation among employees in government institutions $(\mathrm{M}=3.55, \mathrm{SD}=0.796)$. From the results, employee's level of skills determines employee's compensation $(\mathrm{M}=3.98, \mathrm{SD}=0.778)$; this shows that employees with higher level of skills were well remunerated as compared to those who had lower qualifications.

The results also suggest that job experience determines compensation among employees in government institutions as evidenced by mean 3.34, this shows that employees who had higher job experienced received higher compensation. It can be inferred from the results (Table 4.8) that years of experience in government institutions determine employee's compensation as evidenced by the mean of 3.64, this shows that employees who had worked for many years received higher compensation. The tabulated result also suggests that that participation in internship contributes to higher pay among employees in public institutions as evidenced by the mean of 3.85, this shows that internship was part of job experience which determined employee's compensation. From the findings, organization learning determines compensation among employees 
in public institutions as evidenced by the mean of 3.97, this shows that that employees who participated in organization learning received higher pay.

The results also suggest that the ministry provides equal training opportunities for all employees to advance their careers as evidenced by the mean of 3.44, this shows that the ministry had training programmes available for all employees. There were also compensation related promotion opportunities in this organization as evidenced by the mean of 3.57, this shows that the ministries provided opportunities for employees to be promoted. Further, the ministries and state corporations encouraged personal career advancement among the employees as evidenced by the mean of 3.87, this shows that employees had opportunities to advance their career which determined the pay. The results (Table 8) indicate that employees are rewarded for demonstrating initiatives regarding their career advancement as evidenced by the mean of 3.82, this shows that government ministries had reward system for career advancing employees who determined compensation.

Further, respondents found their job exciting as evidenced by the mean of 3.67, this shows that most employees in government ministries liked their jobs. They indicated that they were willing to continue in my current job even if similar one is available elsewhere as evidenced by the mean of 3.80, this shows that majority of employees who participated in the study were satisfied with their job. Majority of respondents indicated that "the job provides me with the needed opportunity for growth" as evidenced by the mean of 3.92, this shows that employees in government ministries have time to grow their career. Further, a majority of respondents indicated that they would recommend someone to take up a job in this organization as evidenced by the mean of 4.10 , this shows that employees were happy working in government ministries.

\subsection{Strength of the Relationship between Variables}

To examine the strength of the relationship between pairs of variables, correlation analysis using Pearson Correlation was performed and the results are found in Table 9. The significance of the correlation coefficients was tested at $95 \%$ confidence level and 5\% significance level $(\mathrm{p}<0.05)$.

\begin{tabular}{|c|c|c|c|c|c|c|}
\hline & COAV & EAV & LAV & JAV & CAV & JSAV \\
\hline Compensation Disparity (COAV) & 1 & & & & & \\
\hline Employee rank (EAV) & $.436^{* *}$ & 1 & & & & \\
\hline & $\varangle 0.001$ & & & & & \\
\hline Level of Education (LAV) & $.286^{* *}$ & $.524^{* *}$ & 1 & & & \\
\hline & 0.004 & $<0.001$ & & & & \\
\hline Job experience (JAV) & $.310^{* *}$ & $.480^{* *}$ & $.534^{* *}$ & 1 & & \\
\hline & 0.002 & $\varangle 0.001$ & $\varangle 0.001$ & & & \\
\hline Career advancement (CAV) & $.368^{* *}$ & $.416^{* *}$ & $.551^{* *}$ & $.658^{* *}$ & 1 & \\
\hline & $\varangle 0.001$ & $\varangle 0.001$ & $\varangle 0.001$ & $<0.001$ & & \\
\hline Job satisfaction (JSAV) & 0.189 & 0.19 & $.239^{*}$ & $.518^{* *}$ & $.357^{* *}$ & \\
\hline & 0.062 & 0.061 & 0.017 & $\varangle 0.001$ & $\varangle 0.001$ & \\
\hline & 98 & 98 & 99 & 97 & $\mathbf{9 8}$ & \\
\hline
\end{tabular}

Table 9: Correlations

** Correlation is significant at the 0.01 level (2-tailed)

* Correlation is significant at the 0.05 level (2-tailed)

From the correlation results in Table 4.9, compensation disparity $(r=0.189, p=0.062>0.05$ and employee rank $(\mathrm{M}=0.19, \mathrm{p}=0.061>0.05)$ had no significant relationship with job satisfaction although the relationship was positive.

Table 9 shows weak positive relationship between employee rank and job satisfaction while there is a strong relationship between job experience and job satisfaction. The relationship is significant $(r=0.518, p<0.001)$, thus job experience (JAV) was strongly related with job satisfaction. There is also a positive relationship between career advancement and job satisfaction, the relationship is significant $(r=0.357, p<0.001)$, thus career advancement was significantly correlated with job satisfaction. Further, Employee rank (EAV), Level of Education (LAV), Job experience (JAV), and Career advancement (CAV) had positive and significant $(\mathrm{p}<0.01)$ relationship with compensation disparity with the strongest correlation $(r=0.436, p \varangle 0.001)$ being between employee rank and perception of compensation disparity and the weakest $(r=0.286, p=0.004 \varangle 0.01)$ being between level of education and compensation disparity.

\subsection{Influence of Disparity Factors on Compensation Disparity}

Perception of compensation disparity (COAV) was regressed on Employee rank (EAV), Level of Education (LAV), Job experience (JAV), and Career advancement (CAV) and the results are presented in Table 10, (Model Summary), Table 10 (Analysis of variance, ANOVA) and Table4.12 (coefficients of regression). In this analysis, the factors that influenced perception of compensation disparity were examined. 


\begin{tabular}{|c|c|c|c|c|}
\hline Model & $\mathbf{R}$ & $\begin{array}{c}\mathbf{R} \\
\text { Square }\end{array}$ & $\begin{array}{c}\text { Adjusted R } \\
\text { Square }\end{array}$ & $\begin{array}{c}\text { Std. Error of the } \\
\text { Estimate }\end{array}$ \\
\hline 1 & $.486 \mathrm{a}$ & 0.236 & 0.202 & 0.611295 \\
\hline
\end{tabular}

Table 10: Model Summary

Predictors: (Constant), CAV, EAV, LAV, JAV

As shown in Table 10, the data that was collected and analyzed exhibited a model fit $\left(\mathrm{R}^{2}=0.236\right)$ with the combination Employee rank (EAV), Level of Education (LAV), Job experience (JAV), and Career advancement (CAV) significantly explaining $23.6 \%$ of the variation in compensation disparity perception in the ministries.

\begin{tabular}{|l|l|l|l|l|l|l|}
\hline \multicolumn{7}{|c|}{ ANOVAa $^{\text {a }}$} \\
\hline Model & & $\begin{array}{l}\text { Sum of } \\
\text { Squares }\end{array}$ & Df & $\begin{array}{l}\text { Mean } \\
\text { Square }\end{array}$ & F & Sig. \\
\hline 1 & Regression & 10.391 & 4 & 2.598 & 6.952 & $.000^{\mathrm{b}}$ \\
\hline & Residual & 33.631 & 90 & 0.374 & & \\
\hline & Total & 44.022 & 94 & & & \\
\hline
\end{tabular}

Table 11: Analysis of Variance

Dependent Variable: COAV

Predictors: (Constant), CAV, EAV, LAV, JAV

Further, the combination Employee rank (EAV), Level of Education (LAV), Job experience (JAV), and Career advancement (CAV) significantly explained the variation in compensation disparity (F-stat $=6.952, \mathrm{p}<0.001)$; see Table 4.10

\begin{tabular}{|c|c|c|c|c|c|c|}
\hline \multicolumn{9}{|c|}{ Coefficients $^{\mathbf{a}}$} \\
\hline Model & \multicolumn{2}{|c|}{$\begin{array}{c}\text { Unstandardized } \\
\text { Coefficients }\end{array}$} & $\begin{array}{c}\text { Standardized } \\
\text { Coefficients }\end{array}$ & $\mathrm{t}$ & Sig. \\
\hline 1 & B & Std. Error & Beta & & \\
\hline & $\begin{array}{c}\text { Employee } \\
\text { rank }\end{array}$ & 0.331 & 0.114 & 0.328 & 2.909 & 0.005 \\
\hline & $\begin{array}{c}\text { Level of } \\
\text { education } \\
\text { Job } \\
\text { experience }\end{array}$ & 0.02 & 0.152 & 0.017 & 0.134 & 0.894 \\
\hline & $\begin{array}{c}\text { Career } \\
\text { advancement }\end{array}$ & 0.23 & 0.123 & -0.014 & -0.11 & 0.912 \\
\hline & & 0.155 & 0.242 & 1.868 & 0.065 \\
\hline
\end{tabular}

Table 12: Coefficients of Regression

Dependent Variable: Compensation disparity

On examination of the relative influence of the each of the bases of compensation disparity, it was found that at $95 \%$ confidence interval and $5 \%$ level of significance, only employee rank $(\beta=0.331, p=0.005<0.01)$ positively and significantly influenced the civil servants perception of compensation disparity while the Level of Education (LAV), Job experience (JAV), and Career advancement (CAV) had no significant influence at this level of significance, except career advancement $(\beta=0.23$, $\mathrm{p}=0.065$ ) which had a positive and significant influence at $\mathrm{p}<0.1$, that is at $10 \%$ significance level. The level of education and job experience were found not to have any significant influence on the perception of compensation disparity.

\subsection{Influence of Compensation Disparity Dimensions on Job Satisfaction}

The influence of disparity factors on job satisfaction was established using multiple linear regression analysis. The model summary, ANOVA and coefficients of regression are presented in the following tables (Table 13, Table14, and Table15 respectively)

\begin{tabular}{|c|c|c|c|c|}
\hline Model & R & R Square & Adjusted R Square & Std. Error of the Estimate \\
\hline 1 & $.541 \mathrm{a}$ & 0.293 & 0.253 & 0.733896 \\
\hline
\end{tabular}

Table 13: Model Summary

Predictors: (Constant), COAV, LAV, JAV, EAV, CAV 
The model summary shows that the coefficient of determination $\mathrm{R}^{2}$ is 0.293 which implies that all the disparity variables namely perception of compensation disparity (COAV), Employee rank (EAV), Level of education (LAV), Job experience (JAV), and Career advancement (CAD) explained 29.3\% of variation in job satisfaction. This means that about $70 \%$ of variation in job satisfaction can be explained by other factors.

\begin{tabular}{|l|l|l|l|l|c|c|}
\hline \multicolumn{1}{|c|}{ Model } & & Sum of Squares & \multicolumn{1}{c|}{ DF } & Mean Square & F & Sig. \\
\hline 1 & Regression & 19.622 & 5 & 3.924 & 7.286 & $.000^{\mathrm{b}}$ \\
\hline & Residual & 47.397 & 88 & 0.539 & & \\
\hline & Total & 67.02 & 93 & & & \\
\hline
\end{tabular}

Table 14 ANOVA $^{\text {a }}$

Dependent Variable: Job Satisfaction (JSAV)

Predictors: (Constant), COAV, LAV, JAV, EAV, CAV

The regression model was significant $\left(F_{(5,88)}=7.286, p<0.001\right)$ which shows that the model was very significant in explaining the influence of disparity factors on job satisfaction among the civil servants.

The regression coefficients associated with perception of compensation disparity and disparity variables are presented in Table 4.15.

\begin{tabular}{|c|c|c|c|c|c|c|}
\hline Model & & \multicolumn{2}{|c|}{$\begin{array}{c}\text { Unstandardized } \\
\text { Coefficients }\end{array}$} & $\begin{array}{c}\text { Standardized } \\
\text { Coefficients }\end{array}$ & t & Sig. \\
\hline & & B & Std. Error & Beta & & \\
\hline 1 & (Constant) & 1.091 & 0.599 & & 1.822 & 0.072 \\
\hline & Compensation disparities(CAV) & 0.188 & 0.154 & 0.156 & 1.225 & 0.224 \\
\hline & Job Experience (JAV) & 0.803 & 0.192 & 0.519 & 4.177 & $\varangle 0.001$ \\
\hline & Level of Education (LAV) & -0.164 & 0.187 & -0.109 & -0.877 & 0.383 \\
\hline & Employees Rank (EAV) & -0.050 & 0.146 & -0.040 & -0.345 & 0.731 \\
\hline & Career Advancement(COAV) & -0.035 & 0.136 & -0.027 & -0.254 & 0.800 \\
\hline
\end{tabular}

Table 15: Regression Coefficients

Dependent Variable: Job Satisfaction (JSAV)

The respondent's assessment of the extent of compensation disparity had a positive but insignificant ( $\mathrm{B}=0.188$, $\mathrm{p}=0.224 \varangle 0.001)$ influence on job satisfaction, while only job experience positively and insignificantly $(B=0.803, p<0.001)$ influenced and job satisfaction, level of education (LOE), employee rank (ERA), and career advancement (CAD) disparity negatively but insignificantly ( $p>0.05$ ) influenced job satisfaction.

Further, a regression was run for the regression of job satisfaction on compensation factor, namely employee rank, level of education, job experiences and career development (see Table 4.16).

\begin{tabular}{|c|c|c|c|c|}
\hline Model & R & R Square & $\begin{array}{c}\text { Adjusted R } \\
\text { Square }\end{array}$ & $\begin{array}{c}\text { Std. Error of } \\
\text { the Estimate }\end{array}$ \\
\hline 1 & $.547 \mathrm{a}$ & 0.299 & 0.268 & 0.725971 \\
\hline
\end{tabular}

Table 16: Model Summary for Job Satisfaction on Compensation Factors

Predictors: (Constant), CAV, EAV, LAV, JAV

The model fit results were an R-square $\left(\mathrm{R}^{2}\right)$ of 0.299 (Table 4.16), implying that the compensation factors explain $29.9 \%$ of variation in job satisfaction; similar, there was a significant F-statistic ( $F=9.599, \mathrm{p}<0.001)$ (Table 17) suggesting that the model was significant and that the data fit the model.

\begin{tabular}{|l|l|l|l|l|l|c|}
\hline Model & & $\begin{array}{c}\text { Sum of } \\
\text { Squares }\end{array}$ & \multicolumn{1}{c|}{ df } & $\begin{array}{c}\text { Mean } \\
\text { Square }\end{array}$ & F & Sig. \\
\hline 1 & Regression & 20.236 & 4 & 5.059 & 9.599 & $\varangle 0.001^{\mathrm{b}}$ \\
\hline & Residual & 47.433 & 90 & 0.527 & & \\
\hline & Total & 67.669 & 94 & & & \\
\hline
\end{tabular}

Table 17: Anovaa

Dependent Variable: JSAV

Predictors: (Constant), CAV, EAV, LAV, JAV 
The ANOVA results imply that the model was significant at $p<0.001$. The coefficients of regression are presented in Table 18 with respective regression coefficients

\begin{tabular}{|c|c|c|c|c|c|c|}
\hline \multicolumn{7}{|c|}{ Coefficients $^{\mathbf{2}}$} \\
\hline Model & & \multicolumn{2}{c|}{$\begin{array}{c}\text { Unstandardized } \\
\text { Coefficients }\end{array}$} & $\begin{array}{c}\text { Standardized } \\
\text { Coefficients }\end{array}$ & t & Sig. \\
\hline & & B & $\begin{array}{c}\text { Std. } \\
\text { Error }\end{array}$ & Beta & & \\
\hline 1 & (Constant) & 1.065 & 0.583 & & 1.825 & 0.071 \\
\hline & Employee rank & -0.063 & 0.135 & -0.05 & -0.468 & 0.641 \\
\hline & Level of education & -0.162 & 0.184 & -0.107 & -0.879 & 0.382 \\
\hline & Job experience & 0.800 & 0.188 & 0.52 & 4.259 & $<0.001$ \\
\hline & Career advancement & 0.179 & 0.147 & 0.148 & 1.220 & 0.226 \\
\hline
\end{tabular}

Table 18: Regression Coefficients for the Regression of Job Satisfaction on Compensation Factors Dependent Variable: Job Satisfaction (JSAV)

In addition, only job experience had a significant influence on job satisfaction with $p$-value less than 0.001 ( $p<0.001)$. The influence of employee rank and level of education were negative and insignificant $(p>0.05)$, while that of career development was positive but not significant $(\beta=0.179$, $p>0.05)$.

These results imply that only job experience significantly $(\beta=0.8, p<0.001)$ influences job satisfaction; the influence is positive while all the other three compensation disparity factors did not significantly ( $p>0.05$ for all coefficients) influence job satisfaction in the civil service.

Only employee rank significantly $(0.331, \mathrm{p}=0.005 \mathrm{p}<0.05)$ explain compensation disparity in the public service; similarly, career advancement $(\beta=0.23)$ is significant in explaining compensation disparity but at $\mathrm{p}=0.065<0.1$ ) (see Table 4.9).

All the four compensation disparity factors (employee rank, level of education, job experience and career development) were positively and significantly correlated with compensation disparity (Table 4.9). This notwithstanding, overall the findings suggest that the respondents are almost indifferent regarding whether compensation disparity exists in the civil service $(\mathrm{M}=3.09, \mathrm{SD}=0.68$ ).

The results also suggest that though insignificant, compensation differences based on level of education and employee rank negatively influence job satisfaction among civil servants. On the other hand, compensation differentiation among civil servants on the basis of employees' career development is positive though not significant $(\beta=0.179, p=0.226)$.

It is noted that there is scarce empirical literature that links compensation disparity factors with job satisfaction in the civil service and this one of the first attempts to understand this relationship.

The results also suggest that the ministry provides equal training opportunities for all employees to advance their careers. In addition, there were compensation related promotion opportunities in this organization and that the ministry encouraged staff career advancement among the employees with accompanying rewards for staff who demonstrated initiatives regarding their career advancement.

These results imply that only job experience significantly $(\beta=0.8, p<0.001)$ influences job satisfaction; the influence is positive while all the other three compensation disparity factors did not significantly ( $p>0.05$ for all coefficients) influence job satisfaction in the civil service.

Only employee rank significantly explains compensation disparity in the public service. Further, all the four compensation disparity factors (level of education, employee rank, job experience and career development) are positively and significantly correlated with compensation disparity and are therefore compensation disparity factors.

\section{Conclusion and Recommendations}

The purpose of the study was to establish what the compensation disparity factors were among civil servants in Kenya and to establish the relationship between compensation disparity factors (employee rank, level of education, working (job) experience, and career advancement) on job satisfaction among the civil servants in Nairobi County, Kenya.

It was found that the level of education was a determinant of employee's compensation differences among employees in government institutions. Employee's professional qualification was found to determine the difference in compensation among employees in government institutions. Employee's level of training determines compensation among employees in government institutions. Further, job experience accounts for compensation differentiation among employees in government institutions when years of experience in government institutions determined employee's compensation.

In summary, employees' level of education, employee rank, working (job) experience, and career advancement are compensation disparity factors in the civil service in Kenya; this is to say that the level of compensations depends on these factors. Further, compensation differentiation based on employee rank had no significant influence on job satisfaction among 
civil servants, and that the application of compensation disparity based on the level of education had no significant influence on job satisfaction among the civil servants in Kenya. Conversely, working (job) experience as the basis for compensating civil servants differently had a positive and significant influence on job satisfaction among the civil servants in Kenya while compensating employees based on their career advancement had no significant effect on job satisfaction among the civil servants.

However, the combination of all the four compensation disparity factors as bases for differentiating the compensation of civil servants significantly explained the variation in job satisfaction among civil servants in government ministries

\subsection{Conclusion}

The study concludes that there exists compensation disparity among employees in the public sector based on employees' level of education, employee rank, working (job) experience, and career advancement.

On the other hand, these results imply that only job experience significantly $(\beta=0.8, p<0.001)$ influences job satisfaction; the influence is positive while all the other three compensation disparity factors did not significantly ( $p>0.05$ for all coefficients) influence job satisfaction in the civil service. Further, though all compensation factors were correlated with compensation disparity (differentiation in compensation), only employee rank significantly explained compensation disparity in the public service when compensation disparity was regressed on the four compensation disparity determinants (factors) namely, level of education, job experience, employee rank and extent of career advancement of an employee (civil servant).

Lastly, it is noted that there is scarce empirical literature that links compensation disparity factors with job satisfaction in the civil service and this one of the first attempts to understand this relationship.

\subsection{Recommendations of the study}

Based on the findings of this study, there should be harmonization of salaries by civil service for all civil servants in parastatals and the ministries and across the job groups. Employees in the same job group should have similar remuneration in ministries and the parastatals.

The civil service should review the ranking of employees to ensure a civil servant is promoted on merit. It should also consider employees who have risen through the rank for better pay. Each rank should have its pay scale. A rise in employee's rank should lead to higher compensation.

Civil servants should be given an opportunity to advance their education hence their career. Employees who attain high level of education should be considered in compensation decisions in order to ensure job satisfaction. In addition, employee's level of skills in government ministries and parastatals should be regularly evaluated to match with their pay.

The number of years the employee has worked should be a major consideration when deciding how much employees will be compensated in government institutions. Employees who have stayed in the organization for a long time should be paid better which is expected to lead to job satisfaction as found in this study, that if civil servants are compensated based on job experience this would positively and significantly influence their job satisfaction which would lead to better performance. The compensation of employee's in government institutions should therefore be commensurate with job experience.

The findings suggest that career advancement opportunities should lead to job satisfaction of employees in government institutions. The government should support employees in government ministries and parastatals who want to advance career advancement opportunities.

\section{Suggestion for Further Study}

These findings suggest that the civil servants may not be satisfied with the basis upon which compensation is differentiated among them. A study examines this phenomenon is also recommended.

\section{References}

i. Bozeman, B., \& Gaughan, M., (2011). Job Satisfaction among University Faculty: Individual, Work and Institutional Determinants. Journal of Higher Education, 82(2), 154-186

ii. Blomme, R. J., Van Rheede, A., \& Tromp, D. M. (2010). The use of the psychological con-tract to explain turnover intentions in the hospitality industry: a research study on the impact of gender on the turnover intentions of highly educated employees. The International Journal of Human Resource Management, 21(1), 144-162.

iii. Boushey, H., \& Glynn, S. J. (2012). There are significant business costs to replacing employees. $4^{\text {th Edition. McGraw-Hill }}$ Publisher. U.S.A. New York.

iv. Choi, S. L., \& Lee, Y. T. (2012). Employees' turnover intention: a leadership issue? International Journal of Future Computer and Communication, 1(3), 229-230.

v. Dawson, J. F. (2013). Moderation in management research: what, why, when, and how. Journal of Business and Psychology. DOI: 10.1007/s10869-013-9308-7.

vi. Gilley, A., Gilley, J., \& McMillan, H. (2009), "Organizational Change: Motivation, Communication, and Leadership Effectiveness", Performance Improvement Quarterly 21(4):75-94.

vii. Gilley, A., Dixon, P.\&Gilley, J. W.(2008).Characteristics of Leadership Effectiveness: Implementing Change and Driving Innovation in Organizations. Human Resource Development Quarterly, 19(2): 153-169. 
viii. Githinji, A. M. (2010).Factors Influencing Secondary School Teachers Job Satisfaction 4thEdition. McGraw-Hill Publisher. U.S.A. New York.

ix. Hashim, R. \&Mahmood, R. (2011). What Is the State Of Job Satisfaction among Academic Staff At Malaysian Universities? Unitar E-Journal, 7(1), 15-26.

x. Kombo, M. N., \& Tromp, P. H. (2006). Research Methods, 3rdEd.:New York, U.S.A:McGraw-Hill Publisher

xi. Kothari, .C. R. (2006), Research Methodology,1ed. London,UK: Pitman Publisher.

xii. Peil S. K. (2005). Research Methodology and Design, 5th Edition, New York, U.S.A.: Macmillan. Publishers.

xiii. Pouliakas, K. (2010). Pay Enough, Don't Pay Too Much or Don't Pay at All? The Impact of Bonus Intensity on Job Satisfaction.Kyklos, 63(4), 597-626. doi:10.1111/j.1467- 6435.2010.00490

xiv. Shah, A. (Ed.) (2007).Performance Accountability and Combating Corruption, 1stEdition.. London, UK: Pitman Publication.

xv. Udogo, F.S. (2008). Determinants of Job Satisfaction of Federal Government Employees. Public Personnel Management, 26(3), 313-334.

xvi. Yamoah, E. E. (2013). Reward Systems and Teachers' Performance: Evidence from Ghana, Canadian Social Science,9 (5), 57-62.

xvii. Zikmund, W. (2010). Business Research Methods 8thEdition.McGraw-Hill Publishers. 